Review

http://dx.doi.org/10.17784/mtprehabjournal.2014.12.195

\title{
Sleep during, overweight and obesity in adolescence: a systematic review.
}

\section{Duração do sono, sobrepeso e obesidade na adolescência: uma revisão sistemática.}

\author{
Maritza Lordsleem Silva(1), Raphael José Perrier Melo(1), Penelopy Dabbicco(2), Clara Maria Silvestre \\ Monteiro de Freitas $^{(3)}$. \\ Escola Superior de Educação Física, Universidade de Pernambuco (ESEF/UPE), Recife (PE), BraZil.
}

\begin{abstract}
Introduction: In adolescence, intense social and school demands, hormonal changes that modify the circadian rhythms and the overuse of electronic equipments causes an inadequate sleep duration to adolescents. Studies have linked short sleep duration with the increase odds to have overweight and obesity. Objective: To identify articles that analyzed relationship between inadequate sleep time and overweight and obesity in adolescents. Method: It was done a research on Bireme (Lilacs and MEDLINE), PubMed, Scielo and Ibecs for two independents researchers using Portuguese and English keywords: "sleep", "sleep duration", "adolescence", "obesity" and "overweigh". It was considerated as inclusion criteria: sample with 10-19-year adolescents, original articles between 2002 and 2013 in Portuguese and English. Therefore, it was excluded review articles, thesis, dissertations and monographs. Results: The initial Electronic search resulted in 663 articles and, after process of article select with read of titles, resumes and the complete form, it was selected 15 articles. Conclusion: Inadequate levels of sleep duration are associated with increase of overweight and obesity in adolescents.
\end{abstract}

Keywords: Adolescents. Sleep. Overweight. Obesity.

\section{Resumo}

INTRODUÇÃO: Na adolescência, as intensas demandas sociais e de atividade escolares, as mudanças hormonais que alteram o ritmo circadiano, além do uso excessivo de equipamentos eletrônicos fazem com que os adolescentes tenham uma duração inadequada do sono. Estudos tem associado uma curta duração de noites de sono ao aumento das chances de ter sobrepeso e obesidade. OBJETIVO: Identificar estudos que analisaram a relação entre tempo de sono inadequado e sobrepeso e obesidade em adolescentes. MÉTODO: Foi realizada uma pesquisa nas bases de dados Bireme (Lilacs e MEDLINE), PubMed, Scielo e Ibecs, por dois pesquisadores independentes, utilizando os seguintes descritores nas línguas portuguesa e inglesa: "sono", "duração do sono", "adolescência", "obesidade" e "sobrepeso". Considerou-se como critérios de inclusão: amostra com adolescentes de 10 a 19 anos, publicações originais entre 2002 e 2013 nos idiomas Português e Inglês. Assim, foram excluídos artigos de revisão, teses, dissertações e monografias. RESULTADOS: A busca eletrônica inicial resultou em 663 manuscritos, no qual, após o processo de seleção dos artigos que envolveu a leitura de títulos, resumos e textos completos, selecionamos 15 estudos que preencheram os critérios de inclusão. CONCLUSÕES: Níveis inadequados na duração do sono estão associados com o incremento do sobrepeso e obesidade em adolescentes.

Palavras-chave: Adolescentes. Sono. Sobrepeso. Obesidade.

Received: 9 June 2014. Accepted: 8 September 2014. Published: 16 September 2014.

1. Professor of Physical Education Post Graduated program, Universidade de Pernambuco, Recife (PE), Brazil.

2. Master in Physical Education, Universidade de Pernambuco, Recife (PE), Brazil.

3. Doctor in Physical Education and Professor, Universidade de Pernambuco, Recife (PE), Brazil.

Corresponding Author:

Maritza Lordsleem Silva - Escola Superior de Educação Física / Universidade de Pernambuco - Avenida Agamenon Magalhães, S/N Bairro de Santo Amaro, Recife (PE), Brazil - Zip Code: 50100-010 - Phone: (081) 85432400 - e-mail: maritzalordsleem@hotmail.com. 


\section{INTRODUCTION}

Overweight and obesity have been considered relevant public health issues and has been gaining prominence on the world stage, both developed in those of low and middle income countries. ${ }^{(1)}$ Thus, it is estimated that $40.6 \%$ of Brazilian adults are overweight, and this condition has increased progressively earlier ages. ${ }^{(2)}$

In this sense, the increasing prevalence of overweight and obesity among adolescents has tripled in the last four decades, (3) has aroused interest among researchers and health professionals. This concern is due to the positive association between overweight and obesity with metabolic, cardiovascular, pulmonary, orthopedic and psychological, ${ }^{(4,5)}$ beyond the complications linked to this epidemic economic and social repercussions. $(6,7,8)$

In this perspective, realizing adolescence as a period in which a variety of psychosocial conflicts, resulting from intense physical, psychological and social changes, ${ }^{(9)}$ occurs, one can understand the fact sleepless nights and sleep with short term needs are common in this population. ${ }^{(10-13)}$ Thus, it is estimated that over $30 \%$ of children and adolescents in the world have sleep disorders that, somehow, will affect the time spent in bed. $(14,15,16)$

This way, studies ${ }^{(17,18)}$ shows that most teenagers sleeping around seven hours per night, about an hour less than their estimated sleep need. This reduction of sleep adolescents would be linked to increased social demands, the insertion in the world of work, to school activities, the hormonal changes that alter the circadian rhythm, and the overuse of electronic equipment.(19)

In this scenario, studies suggest that inadequate sleep duration is associated with an increased odds of being overweight and obesity. ${ }^{(20,21,22)}$ In this case, the underlying mechanisms of this association, although not fully understood, would be a reduction in spending energy, increased chances of eating, changes in appetite regulatory hormones, increased sympathetic nerve activity, which spilled over in decreased resting metabolic rate, weight gain and obesity. ${ }^{(20,23)}$

Thus, given the scenario presented on adolescence, time spent on the bed and excess body fat, the aim of this study was to analyze the relationship between sleep duration and obesity in overweight adolescents, through a systematic literature review.

\section{METHODS}

This study employed a methodology based on systematic review, which added information from a set of previous studies(24) Thus, the search of scientific articles were performed by two independent researchers, in electronic databases: BIREME (MEDLINE and Lilacs), PubMed, SciELO and IBECS. Were used the descriptors "Sleep", "sleep duration", "teen", "obesity" and "overweight" in Portuguese and English languages for searche the. In addition, we resorted to the logical operators "AND" and "OR" to combine descriptors and terms used to search publications.

After the search procedure, was identified initially, a total of 1083 articles and subsequently selected articles that met the inclusion criteria: a) sample of adolescents aged 10-19 years, ${ }^{(25)}$ b) publications between the years 2002 and 2013 in Portuguese and English; c) original research articles with humans. To this end, we chose not to include review articles, theses, dissertations and monographs.

\section{RESULTS}

After the first analysis, we found 1,083 publications, then 663 (MEDLINE $=176$, LILACS $=10$, PUB$M E D=186$, SCIELO $=235$ and $\mathrm{IBECS}=56$ ) were eligible for the second phase of this review, which consisted of the reading of summaries. Later evaluation of the abstracts, studies that met the inclusion criteria were read in full. At the end, 15 articles met all the selection criteria, as in figure 1 .

In table 1 are presented chronologically general information about the 15 included studies. Of these, five used longitudinal design, $(6,29,35,37,38)$ and the others had type sectional study $(18,26,27,28,30,31,32,33,34,36)$ with sample from 133 to 73.836 subjects, composed of adolescents aged between $10-19$ years. ${ }^{(25)}$

This way, only three $\operatorname{articles}^{(29,33,37)}$ stated in their results, no significant association between a few hours of sleep, with increased adiposity, the Body Mass Index (BMI) and obesity in adolescents, the others claimed that sleep duration with short of requirements $(\leq 7$ hours) is significantly associated with increased odds of being overweight and obesity.

According to table 1 , the articles analyzed were conducted in several countries, however, there was a higher prevalence for the United States, gathering $60 \%$ of

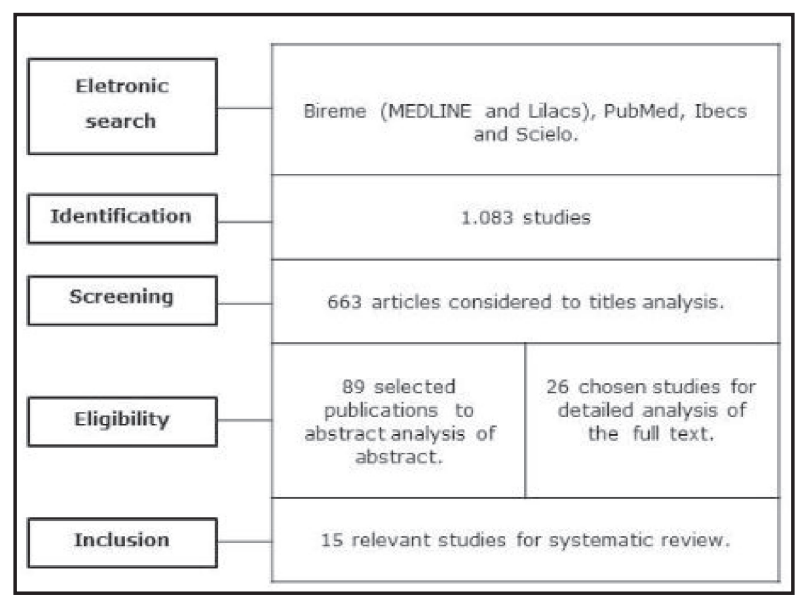

Figure 1. Identification and Studies selection. 


\begin{tabular}{|c|c|c|c|c|c|c|c|c|c|c|c|c|c|c|c|}
\hline $\begin{array}{l}\frac{0}{0} \\
\frac{0}{3} \\
\frac{3}{0} \\
\text { ¿ }\end{array}$ & 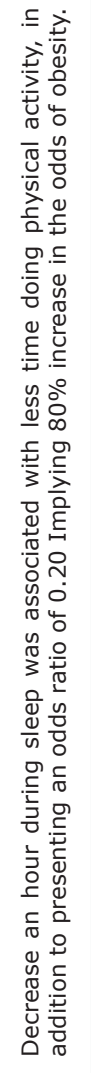 & 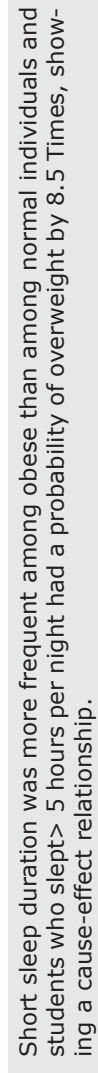 & 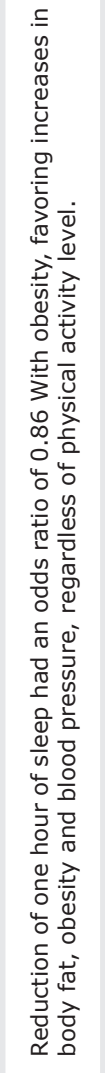 & 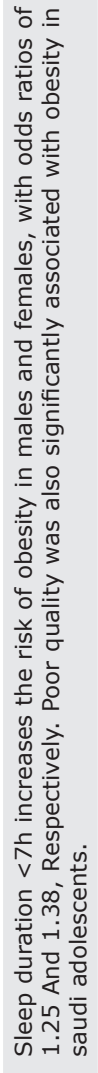 & 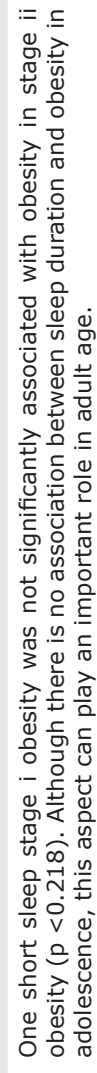 & 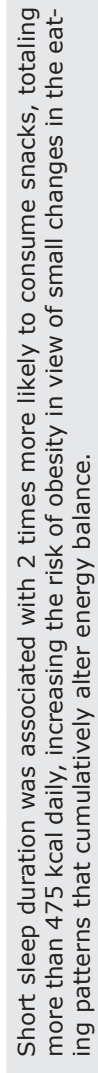 & 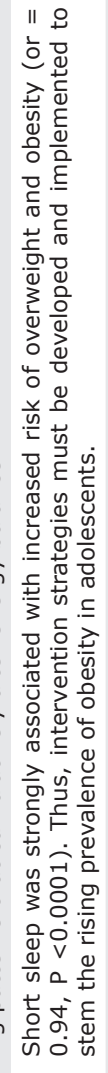 & 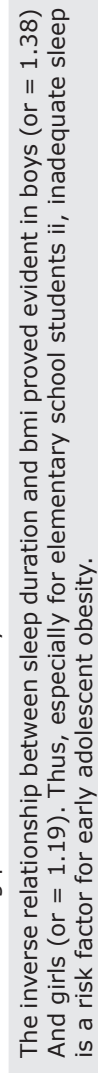 & 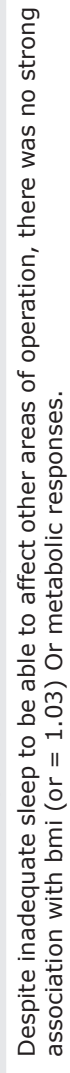 & 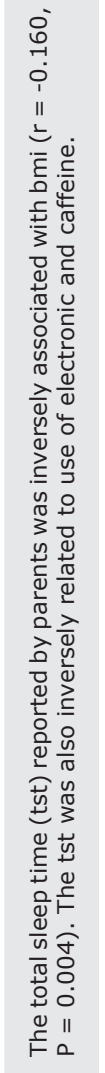 & 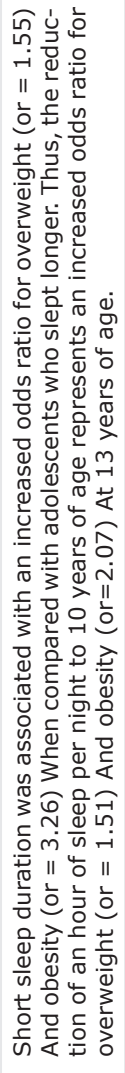 & 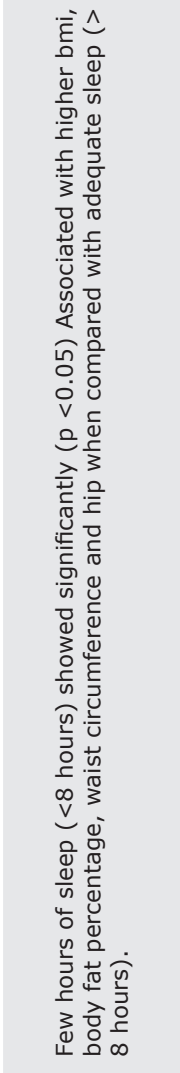 & 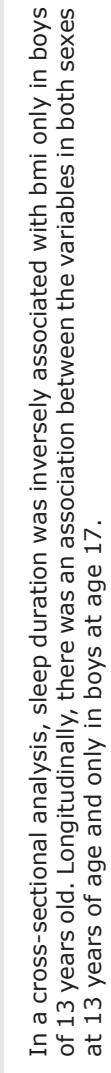 & 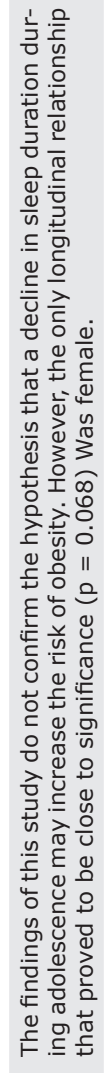 & 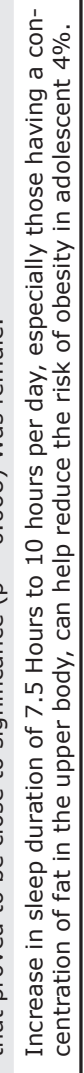 \\
\hline 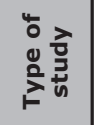 & 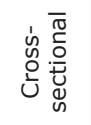 & 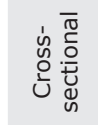 & 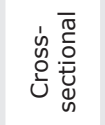 & 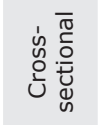 & 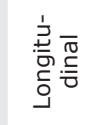 & 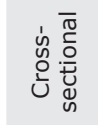 & 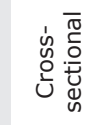 & 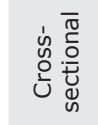 & 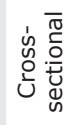 & 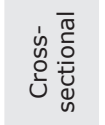 & 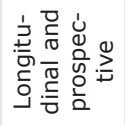 & 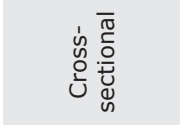 & 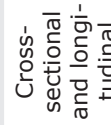 & & \\
\hline 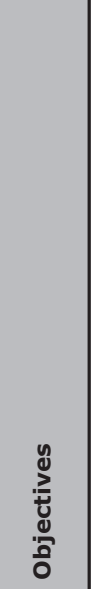 & 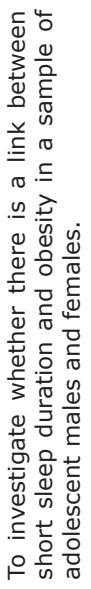 & 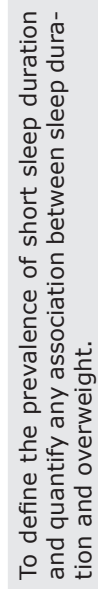 & 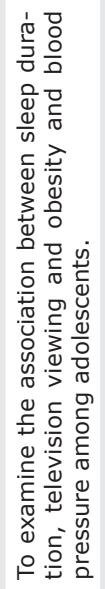 & 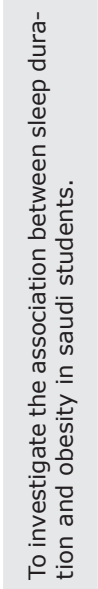 & 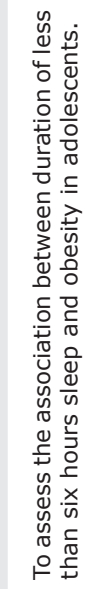 & 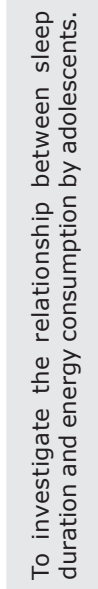 & 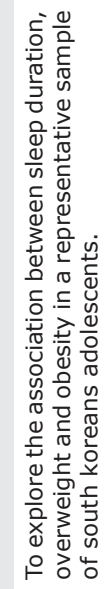 & 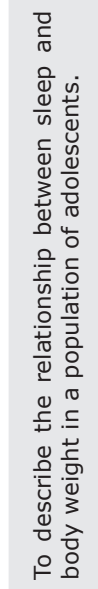 & 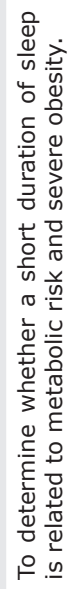 & 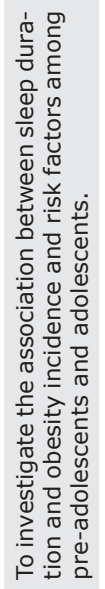 & 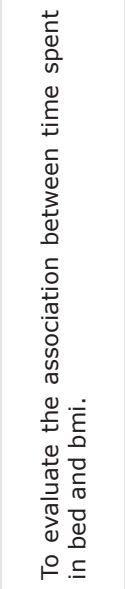 & 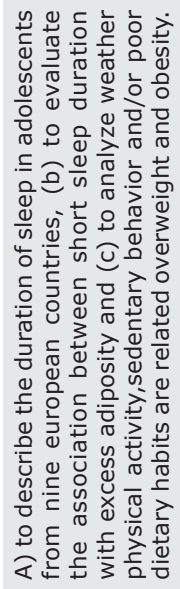 & $\begin{array}{l}\overline{0} \\
\frac{0}{0} \\
\frac{0}{0} \\
0 \\
\frac{0}{0} \\
\frac{0}{n}\end{array}$ & 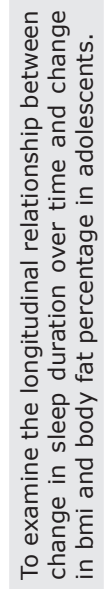 & 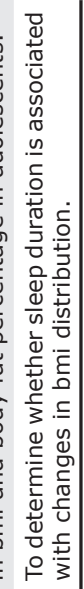 \\
\hline 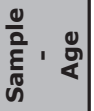 & m & ָึ & 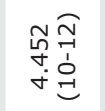 & 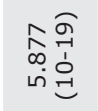 & 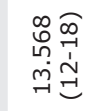 & 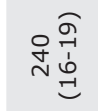 & 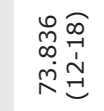 & 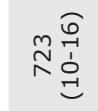 & 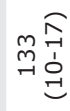 & 월 & $\underset{\rightarrow}{\stackrel{m}{1}}$ & & & 产 & \\
\hline 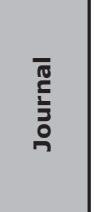 & 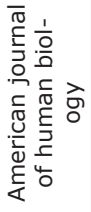 & 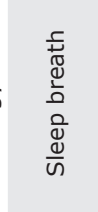 & 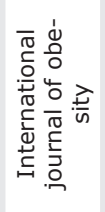 & $\begin{array}{l}\frac{\tilde{y}}{0} \\
\text { Oे }\end{array}$ & 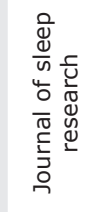 & $\frac{\bar{Q}}{\frac{\mathbb{Q}}{\omega}}$ & 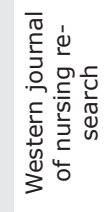 & 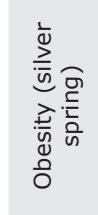 & $\frac{\stackrel{o}{d}}{\omega}$ & 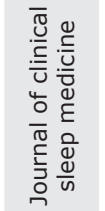 & 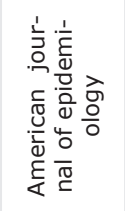 & 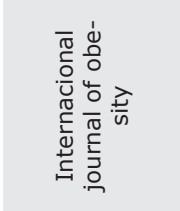 & & 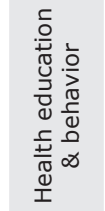 & \\
\hline 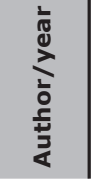 & 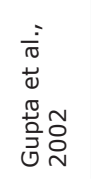 & 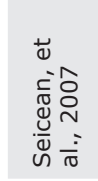 & 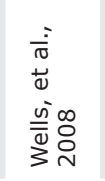 & 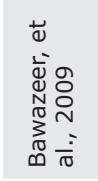 & 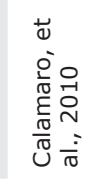 & 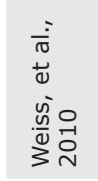 & 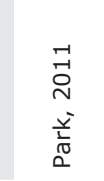 & 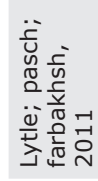 & $\vec{\omega} \mathcal{N}$ & 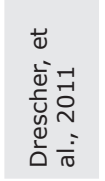 & $\begin{array}{l}\vec{\Delta} \\
\bar{y} \\
\bar{d} \\
\bar{\sigma}\end{array}$ & & 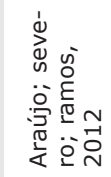 & $\begin{array}{l}\overrightarrow{0} \\
\underline{\Delta} \tilde{\underline{v}}\end{array}$ & \\
\hline
\end{tabular}


the studies $(18,26,29,30,32,33,34,37,38)$ the rest were distributed between South America(27), Asia(28,31), North Ameri$\mathrm{ca}^{(35)}$, and Europe ${ }^{(6,36)}$.

\section{DISCUSSION}

Given the scenario presented in the review and the results, there is the involvement of adolescents with inadequate habits and insufficient sleep according to the minimum recommendations ( 8 hours). ${ }^{(17)}$ Such behaviors are due to the increase in social, school and work, hormonal changes and demands increased utilization of technologies by adolescents, ${ }^{(19)}$ and can lead to serious damage to health and quality of life as well as the emergence and worsening of diseases, obesity being the focus of the present study.

In this sense, studies $^{(18,39)}$ claim that $45 \%$ of teenagers sleep about an hour less than their estimated sleep need. ${ }^{(17)}$ Furthermore, we identified that a duration of less than 7 hours sleep is associated with increases in body fat ${ }^{(28,36)}$, increased participation in sedentary leisure activities such as watching TV, using the computer and playing video games ${ }^{(27,29,31,34,36)}$, decrease body movement $(26,36,37)$, as well as eat foods high in fat and carbohydrate(30), favoring negative changes in BMI classification method used in all studies to determine whether subjects had levels of overweight and/or obesity.

According to Patel and $\mathrm{Hu}^{(23)}$, increments of hunger due to changes in appetite regulating hormones (ghrelin and leptin), increased opportunities to eat, fatigue and changes related to body temperature, are potential mechanisms involved in this association between short durations of the sleep and increases in body weight and obesity. Thus, the first two conditions were associated with increased caloric intake and the last two with low energy expenditure. In this perspective, Knutson ${ }^{(20)}$ reaffirms that inadequate sleep reduces energy expenditure, increases the chances of eating and alter levels of appetite-regulating hormones. Thus, the increased caloric intake is not offset by an increase in physical exercise, such mechanisms will cause weight gain and eventually obesity.

In this sense, most of the analyzed articles $(6,18$, $29,31,32,34,35,36,37,38)$ considered physical activity as a factor related to the association between sleep duration and overweight and/or obesity. This way, studies of Boscolo et $a^{(41)}$ and Bernard et $a^{(42)}$ reaffirmed the link between physical activity and quality of sleep, to explain that students from lower social classes, who were more physically active, had better quality of hours of sleep instead of teenagers from private schools that adopt more sedentary behaviors due to improved socioeconomic conditions.

In this context, the study of Petribú et a/(43) observed that the proportion of overweight and obesity was higher in those who had a negative perception of sleep quality and showed insufficient levels of physical activity. Nevertheless, studies of Calamaro et al (29), Lytle et al (37) and Sung et al (33) found no significant value for the association between sleep duration and overweight and obesity.

Moreover, among the articles analyzed, only the studies of Sung et $a^{\left({ }^{(33)}\right.}$ and Wells et $a^{(27)}$ analyzed the blood pressure of the subjects and identified association between too little sleep increases with inotropes, particularly systolic blood pressure, increasing the risk of developing cardiovascular disease ${ }^{(4,5)}$.

Regarding the methods used to verify the quantity and quality of sleep, all the studies used validated questionnaires and adapted, however, only those studies Descher et $a^{(34)}$ and Weiss et al(30) used polysomnography, a method classified as a gold standard to assess sleep, and it was seen that the two evaluation techniques were associated in a few hours of sleep with obesity.

It was identified as a possible limitation of this review, that most of the studies analyzed used as a technique for body evaluation method of BMI may not indicate correctly the changes in body composition of adolescents, since this population is under development maturational. Therefore, it is necessary to carry out more studies, longitudinal character, using more specific and reliable methods for analysis of sleep and body composition to establish a consensus on the issue.

\section{CONCLUSION}

Given the scenario presented in the systematic review and the results, there is the involvement of adolescents with inadequate sleep habits and insufficient for their physical and cognitive recovery. Such behaviors are due to increased social demands of school and work, hormonal changes and the increased use of technology by teenagers and can cause serious damage to health and quality of life as well as the development and aggravation of diseases, being obesity focus of the present study.

\section{REFERENCES}

1. World Health Organization. Obesity and overweight. Geneva: World Health Organization; $2013 a$.

2. Brasil. Ministério do Planejamento, Orçamento e Gestão; Instituto Brasileiro de Geografia e Estatística. Pesquisa de Orçamentos Familiares. Antropometria e análise do estado nutricional de crianças e adolescentes no Brasil. Rio de janeiro: IBGE; 2007. 
3. Ogden CL, Carroll MD, Kit BK, Flegal KM. Prevalence of obesity and trends in body mass index among US children and adolescents 1999-2010. Jama. 2012;307:483-490.

4. Sanchez-Villegas A, Field AE, O'Reilly E, Fava M, Gortmaker S, Kawachi I, et al. Perceived and actual obesity in childhood and adolescence and risk of adult depression. J Epidemiol Community Health. 2013;67:81-86.

5. Brasil. Departamento de Nutrologia; Sociedade Brasileira de Pediatria. Obesidade na infância e adolescência-Manual de Orientação. São Paulo: Sociedade Brasileira de Pediatria; 2012.

6. Araújo J, Severo M, Ramos E. Sleep duration and adiposity during adolescence. Pediatrics. 2012;130:1146-1154.

7. Wolfenstetter SB. Future direct and indirect costs of obesity and the influence of gaining weight: Results from the MONICA/KORA cohort studies, 1995-2005. Econ Hum Biol. 2012;10:217-138.

8. Wang LY, Denniston M, Lee S, Galuska D, Lowry R. Long-Term Health and Economic Impact of Preventing and Reducing Overweight and Obesity in Adolescence. J Adolesc Health. 2010;46:467-473.

9. Moreira TMM, Viana DS, Queiroz MVO, Jorge MSB. Conflitos vivenciados pelas adolescentes com a descoberta da gravidez. Rev Esc Enferm USP. 2008;42:312-20.

10. Bernardo MPSL, Pereira EF, Louzada FM, D'Almeida V. Duração do Sono em Adolescentes de Diferentes Níveis Socioeconômicos. J Bras Psiquiatr. 2009;58:231-7.

11. Fricke-Oerkermann L, Plück J, Lehmkuhl G. Prevalence and Course of Sleep Problems in Childhood. Sleep. 2007; $30: 1371-77$.

12. Gibson ES, Powles AC, Thabane L, O'Brien S, Molnar DS, Trajanovic N, et al. "Sleepiness" is Serious in Adolescence: Two Surveys of 3235 Canadian Students. BMC Public Health. 2006;2:116.

13. Perez-Chada D, Perez-Lloret S, Drake C. Sleep disordered breathing and daytime sleepiness are associated with poor academic performance in teenagers. A study using the Pediatric Daytime Sleepiness Scale (PDSS). Sleep. 2007; 30:1698-703.

14. Mindell JA, Kuhn B, Lewin DS, Meltzer LJ, Sadeh A. Behavioral Treatment of Bedtime Problems and Night Waking sin Infants and Young Children. Sleep. 2006;29: 1263-76.

15. Sadeh A, Mindell JA, Luedtke K, Wiegand B. Sleep and Sleep Ecology in the First 3 Years: a Web-Based Study. J Sleep Res. 2009;18:60-73.

16. Van Litsenburg RRL, Waumans RC, Gemke RJBJ. Sleep Habits and Sleep Disturbances in Dutch Children: a population-based study. Eur J Pediatr. 2010; 169:1009-1015.

17. National Sleep Foundation. Adolescent sleep needs and patterns - research report and resource guide. Washington: National Sleep Foundation; 2000.

18. Seicean A, Redline S, Seicean S, Kirchner HI, Gao Y, Sekine M, et al. Association between short sleeping hours and overweight in adolescents: results from a US suburban High School Survey. Sleep Breath. 2007;11: $285-293$.

19. Calamaro CJ, Mason TB, Ratcliffe SJ. Adolescents living the 24/7 lifestyle: effects of caffeine and technology on sleep duration and daytime functioning. Pediatrics. 2009;123:1005-10.

20. Knutson KL. Does inadequate sleep play a role vulnerability to obesity? Am J Hum Biol. 2012;24:361-371.

21. Meyer KA, Wall MM, Larson NI, Laska MN, Neumark-Sztainer D. Sleep duration and body mass index in a sample of young adults. Obesity. 2012;20:1279-1287.

22. Magee $C A$, Iverson DC, Huang $X F$, Caputi P. A link between chronic sleep restriction and obesity: methodological considerations. Public Health. 2008;122:1373-1381.

23. Patel SR, Hu FB. Short sleep duration and weight gain: A systematic review. Obesity. 2008;16:643-653.

24. Linde K, Willich SN. How objective are systematic reviews? Differences between reviews on complementary medicine. J R Soc Med. 2003;96:17-22.

25. World Health Organization. Adolescent Health. Geneva: World Health Organization; $2013 \mathrm{~b}$.

26. Chan W, Meininger JC. Is obesity associated with poor sleep quality in adolescents? Am J Hum Biol. 2002;14:7628.

27. Wells JCK, Hallal PC, Reichert FF, Menezes AMB, Araújo CLP, Victora CG. Sleep Patterns and Television Viewing in Relation to Obesity and Blood Pressure: Evidence from an Adolescent Brazilian Birth Cohort. Int J Obes. 2008;32:1042-1049.

28. Bawazeer NM, Al-Daghri NM, Valsamakis G, AL-Rubeaan KA, Sabico SLB, Huang TTK, et al. Sleep Duration and Quality Associated With Obesity Among Arab Children. Obesity. 2009;17:2251-2253.

29. Calamaro CJ, Park S, Mason TBA, Marcus CL, Weaver TE, Pack A, et al. Shortened Sleep Duration does not Predict Obesity in Adolescents. J Sleep Res. 2010;19:559-566.

30. Weiss A, Xu F, Storfer-Isser A, Thomas A, Levers-Landis CE, Redline S. The association of sleep duration with adolescents' fat and carbohydrate consumption. Sleep. 2010;33:1201-1209.

31. Park S. Association between short sleep duration and obesity among South Korean adolescents. West J Nurs Res. 
$2011 ; 33: 207-23$.

32. Lytle LA, Pasch KE, Farbakhsh K. The Relationship between Sleep and Weight in a Sample of Adolescents. Obesity. 2011;19:324-331.

33. Sung V, Beebe DW, Wake M. Does Sleep Duration Predict metabolic Risk in Obese Adolescents Attending Tertiary Services? A Cross-Sectional Study. Sleep. 2011;34:891-8.

34. Drescher AA, Goodwin JL, Silva GE, Quan SF. Caffeine and Screen Time in Adolescence: Associations with Short Sleep and Obesity. J Clin Sleep Med. 2011;7:337-342.

35. Seegers V, Petit D, Falissard B, Vitaro F, Tremblay RE, Montplaisir J, et al. Short Sleep Duration and Body Mass Index: A Prospective Longitudinal Study in Preadolescence. Am J Epidemiol. 2011;173:621-629.

36. Garaulet M, Ortega FB, Ruiz JR, Rey-López JP, Béghin L, Manios Y, et al. Short sleep duration is associated with increased obesity markers in European adolescents: effect of physical activity and dietary habits. The HELENA study. Int J Obes. 2011;35:1308-1317.

37. Lytle LA, Murray DM, Laska MN, Pasch KE, Anderson SE, Farbakhsh K. Examining the longitudinal relationship between change in sleep and obesity risk in adolescents. Health Educ Behav. 2012;1-9.

38. Mitchell JA, Rodriguez D, Schmitz KH, Audrain-Mcgovern J. Sleep duration and adolescent obesity. Pediatrics. 2013;131:1-7.

39. National Sleep Foundation. Sleep in America Poll. Washington: National Sleep Foundation; 2006.

40. Liu J, Zhang A, Li L. Sleep duration and overweight/obesity in children: Review and implications for pediatric nursing. J Spec Pediatr Nurs. 2012;17:193-204.

41. Boscolo RA, Sacco IC, Antunes HK, Mello MT, Tufik S. Avaliação do padrão de sono, atividade física e funções cognitivas em adolescentes escolares. Rev Port Cien Desp. 2007; 7:18-25.

42. Bernardo MPSL, Pereira EF, Louzada FM, D'Almeida V. Duração do sono em adolescentes de diferentes níveis socioeconômicos. J Bras Psiquiatr. 2009;58:231-7.

43. Petribú, MMV, Tassitano RM, Nascimento WMF, Santos EMC, Cabral PC. Fatores associados ao sobrepeso e à obesidade em estudantes do ensino médio da rede pública estadual do município de Caruaru (PE). Rev Paul Pediatr. 2011;29: 536-545.

44. Müller MR, Guimarães SS. Impacto dos Transtornos do Sono Sobre o Funcionamento Diário e Qualidade de Vida. Estud Psicol (Campinas). 2007;24:519-528.

45. Araújo AC, Lunardi VL, Silveira RS, Thofehrn MB, Porto AR. Relacionamentos e interações no adolescer saudável. Rev Gaucha Enferm. 2010;31:136-142.

46. Enes CC, Slater B. Obesidade na adolescência e seus principais fatores determinantes. Rev Bras Epidemiol. 2010;13:163-71.

47. Silva KLD, Dias FLA, Maia CC, Pereira DCR, Vieira NFC, Pinheiro PNC. A influência das Crenças e Valores Culturais no Comportamento Sexual dos Adolescentes do Sexo Masculino. Rev Enferm UERJ. 2010;18:247-252.

48. Brasil. Fundo das Nações Unidas para a Infância. Situação Mundial da Infância 2011: Adolescência uma fase de oportunidades. Brasília: UNICEF; 2011. 